\title{
SMANJIVANJE BROJA KATOLIKA U BOSNI I HERCEGOVINI I POTREBA DA SE ONO ZAUSTAVI
}

\author{
Tomo Vukšić
}

Sveučilište u Sarajevu

Katolički bogoslovni fakultet

UDK: $(272+314)(497.6)$

ordinarijat.bih@gmail.com

\author{
https://doi.org/10.34075/cs.55.3.6 \\ Pregledni znanstveni rad \\ Rad zaprimljen 1/2020.
}

\section{Sažetak}

Vrlo je uočljivo drastično smanjivanje broja katolika u Bosni $i$ Hercegovini tijekom posljednjih 30 godina. Od 760.852, koliko ih je bilo 1991. godine, prema državnom popisu iz 2013. godine ostalo ih je 544.780, odnosno prema crkvenim procjenama na kraju 2018. na tom području bilo bi 365.688 katolika. Taj proces započeo je za vrijeme rata (1991. - 1995.) progonima $i$ iseljavanjem zbog straha $i$ nastavio se nakon toga zbog nesigurnosti, izostanka i onemogućavanja održivog povratka, novog iseljavanja i negativnog priraštaja.

Katolička Crkva u BiH od 2003. do 2018. godine bilježi gubitak od 99.133 vjernika. Odnosno, Banjolučka biskupija je tijekom posljednjih dvadesetak godina ostala bez $45,71 \%$ vjernika, koji su na njezinu području bili 1999. godine, Sarajevska je ostala bez 32,48 $\%$ u odnosu na 2002. godinu, Mostarska bez 11,75\% nakon 2006., a Trebinjska bez 13,04\% od 2005. godine. U tom općem gubitku vlastiti negativan priraštaj sudjeluje s 23.214, što znači da se iz BiH u tom razdoblju, prema crkvenim procjenama, iselilo 75.919 katolika.

Ovaj rad podijeljen je u šest naslova: Okolnosti i zakonski okviri suvremene društvene zbilje u BiH, Depopulacija i denatalitet pogađaju cijelu BiH, Smanjivanje broja katolika ponovno postao proces, Negativan priraštaj $i$ novo iseljavanje katolika, Uloga državne vlasti $i$ međunarodne zajednice u traženju rješenja te Još neki izazovi Katoličke Crkve u složenom društvu BiH.

Ključne riječi: Smanjenje broja katolika i Hrvata, progon, iseljavanje, negativan priraštaj, neuspio povratak, nedostatak posla, traženje rješenja, državna vlast, međunarodna zajednica, odgovor Crkve. 
Pitanje migracija stanovništva jedna je od najvažnijih i najaktualnijih društvenih, gospodarskih, političkih, socijalnih i etičkih tema posljednjih desetljeća u svijetu, pa i u Europi. A kada se unutar ove teme o velikoj suvremenoj seobi ljudi govori o Bosni i Hercegovini, lako je uočiti da su u tom dijelu svijeta prisutni njezini različiti pojavni načini. Među njima su najvažniji progoni i deportacije zbog ratnog nasilja u nedavnoj prošlosti, dugotrajno onemogućavanje održivoga povratka raseljenih i prognanih te u posljednje vrijeme novo iseljavanje. To novo iseljavanje snažno obilježava sadašnji društveni i crkveni život katolika u $\mathrm{BiH}$ i na njemu je naglasak u ovom izlaganju. No osim iseljavanja na proces smanjivanja broja katolika utječe i njihov negativan prirodni priraštaj, koji je posljednjih godina, kao i iseljavanje, postao opća oznaka i ostalih etničkih i vjerskih skupina.

U skladu s temom, u nastavku će biti govora najprije o nekim oznakama društvenog okruženja u $\mathrm{BiH}$, potom o demografskom stanju katolika i na kraju o nekim izazovima Crkve u složenom društvu BiH.

1. OKOLNOSTI I ZAKONSKI OKVIRI SUVREMENE DRUŠTVENE ZBILJE $\mathrm{U} \mathrm{BIH}$

BiH je već stoljećima, kao što je poznato, zemlja različitih naroda, kultura, civilizacija i religija. Kao takva, jednako dugo je složena i zamršena. Promatrana iz perspektive državne uprave, u posljednja dva stoljeća u njoj su se okušali gotovo svi mogući oblici vlasti, od feudalne teokratske, preko monarhija i diktatura, do današnjeg oblika, koji je mnogo više provizorij negoli demokracija i uređeno društvo. Postojeći oblik je kao neki teatar apsurda, na čijoj sceni se bez prekida izvodi uvijek ista tragikomedija, u kojoj se ubija pravda. A viđena iz kuta projekcija za budućnost, BiH se danas nalazi između barem četiri vrlo prepoznatljive tendencije: održavanja postojećeg stanja, federalizacije, unitarizma i secesionizma. Zato je u njoj iskreni dijalog egzistencijalna potreba, sredstvo za izgradnju pravednog mira, društvenog sklada, ozdravljenje rana iz teške prošlosti te osnaživanje svijesti i poziva vjerskih zajednica da moraju biti moralna vertikala društva.

Prema rezultatima posljednjega popisa stanovništva, u $\mathrm{BiH}$ živi samo oko $15 \%$ katolika. Istodobno, pravoslavaca je oko $31 \%$, a muslimansko stanovništvo naraslo je na nešto iznad 50 \%. To znači da je BiH, nakon Albanije i Kosova, postala treća država u Europi gdje je muslimansko stanovništvo u apsolutnoj većini. To je podatak od nemalog značenja, ne samo za ovo područje nego i mnogo šire. 
Bošnjački muslimani čine apsolutnu većinu u jednom dijelu $\mathrm{BiH}$, a srpski pravoslavci to isto u drugom entitetu, dok su hrvatski katolici manjina na obje strane. To omogućuje česte i mnoge manipulacije usmjerene protiv hrvatskih katolika. A u traženju pravednoga rješenja za ovu situaciju, Hrvati predlažu federalizaciju cijele zemlje, što načelno podupire i Europski parlament, ali to ne prihvaćaju ni Srbi ni Bošnjaci. Naspram tomu, naime, kod Bošnjaka je prisutan snažan unitarizam ili želja za održavanjem barem sadašnjega stanja. Srbi pak često izražavaju želju za povratkom izvornomu Daytonu, a nije im nepoznat čak ni secesionizam, dok međunarodna zajednica uglavnom štiti postojeće stanje.

Hrvate frustrira nepravedna unutrašnja podjela $\mathrm{BiH}$ na dva entiteta, čija upravna struktura u oba slučaja ide na njihovu štetu, zatim neriješeno nacionalno pitanje te činjenica da biračku volju pojedinca i naroda obezvrjeđuje izborni zakon. Taj zakon Hrvatima ni na jednoj razini, gdje su u manjini, ne osigurava mogućnost, da sami sebi izaberu predstavnike. ${ }^{1}$ Time na etičkoj razini legitimitet kao kriterij društvenog predstavljanja biva često spriječen i neetičnost biva legalizirana, a na psihološkoj razini birač pojedinac i narod ostaju frustrirani. To jest, budući da drugi nerijetko odlučuju tko će im biti predstavnik, brojni Hrvati osjećaju se poniženima, jer su tretirani kao da su učenici u školi za djecu s posebnim potrebama. Ta pojava ima kao negativnu posljedicu i to da se u nedogled odgađa unutarhrvatska demokratizacija i zdravi pluralizam, jer postoji potreba za zbijanjem redova. Uz to, majorizacija i opstrukcija, a ponekad i lažan samoproglašeni hrvatski identitet pojedinaca $u$ državnoj upravi i diplomaciji, primjenjuju se na štetu dostojanstva i prava Hrvata, posebice kod donošenja važnih odluka i preuzimanja nekih služba.

Pitanje entitetskih vlada u Federaciji BiH i Republici Srpskoj poseban je problem, jer je u njih strukturalno ugrađena mogućnost preglasavanja i diskriminacije manjine. Naime, voljom visokog predstavnika amandmanski je u ustave oba entiteta intervenirano 2002. godine, te je otada ustavna obveza da se njihove vlade sastoje od predsjednika i 16 ministara.

U skladu s tom odlukom visokog predstavnika u vladi RS je „osam ministara iz reda srpskog, pet iz reda bošnjačkog i tri iz reda hrvatskoga naroda” (čl. 92). U Federaciji BiH vlada ima „osam mini-

Usp. Zvonko MiLnko, Ustavno uređenje Bosne i Hercegovine, Zagreb 2006.; Mato TADIĆ, Ustavni položaj Hrvata u Bosni i Hercegovini od Washingtonskog sporazuma do danas, Mostar 2013.; Mato TADIĆ, Ustavnopravni položaj Hrvata u Bosni i Hercegovini, Mostar 2016. 
stara iz reda bošnjačkog, pet ministara iz reda hrvatskog i tri ministra iz reda srpskog naroda" (IV B čl. 4). Primjenjujući spomenute ustavne propise, $\mathrm{u}$ oba entiteta vlade mogu apsolutnom većinom glasova, lege artis, donositi odluke protiv hrvatskih interesa, a da glasovi hrvatskih ministara to ne mogu spriječiti. Na taj način cijela je $\mathrm{BiH}$, po crti teritorijalne podjele na dva dijela iz Daytona, također na razini političke i upravne moći, koju utjelovljuju ove dvije vlade, u obliku stvarne vlasti podijeljena u dva dijela: većinski srpski i većinski bošnjački, kao što je učinjeno s teritorijem u Daytonu.

U postojećem stanju stvari samo Hrvati traže izmjene izbornog zakona i jamstvo legitimnog predstavljanja, dok ni Srbi ni Bošnjaci ne pokazuju zanimanje za to, a, pravno i realno gledajući, bez njihovih glasova u redovitoj proceduri nije moguće promijeniti zakon. Dapače, u sadašnjem stanju odgovara im da sve ostane kao do sada, dok visoki predstavnik najavljuje da neće koristiti svoje ovlasti i nametati reforme, što bi inače bila druga mogućnost promjene zakona.

Pokoja radikalna islamska skupina prisutna je u $\mathrm{BiH}$. Dogodio se i pokoji atentat sa smrtnim posljedicama, ali, srećom, mnogo manje negoli na nekim drugim stranama.

Državna vlast je 2004. godine donijela Zakon o slobodi vjere i pravnom položaju Crkava i vjerskih zajednica. ${ }^{2}$ Godine 2006. je sa Svetom Stolicom potpisala Temeljni ugovor, ${ }^{3}$ a 2010. i Ugovor o dušobrižništvu vojnika i osnutku Vojnog ordinarijata. ${ }^{4}$ Njihova provedba još uvijek čeka, čak i na vrlo jednostavnim pitanjima, kao što je ozakonjenje vjerskih blagdana. Gotovo jednaka situacija je s ugovorom koji je $\mathrm{BiH}$ potpisala sa Srpskom pravoslavnom Crkvom, a koji je uglavnom kopija onoga potpisanoga sa Svetom Stolicom. No sličan ugovor s Islamskom zajednicom još uvijek nije potpisan. U prošlosti je ta zajednica smatrala da joj takav ugovor nije potreban. U novije pak vrijeme predloženi ugovor s tom zajednicom, kako neki kažu, sadržavao bi pozitivnu diskriminaciju, jer navodno predviđa veća prava Islamskoj zajednici negoli drugima.

Neka vjerska prava često su samo djelomično poštovana, kao na primjer: poštivanje slobode vjere, autonomija vjerskih zajednica, poučavanje vjeronauka u svim odgojnim ustanovama, položaj i

2 Usp. „Službeni glasnik BiH”, br. 5/2004. (9. ožujka 2004.).

3 Usp. „Conventio inter Apostolicam Sedem et Bosniam et Herzegoviam. Basic Agreement between the Holy See and Bosnia and Herzegovina", Acta Apostolicae Sedis br. 11/2007., str. 939-946 (2. studenoga 2007.); „Službeni glasnik BiH Međunarodni ugovori”, br. 10/2007. (18. listopada 2009.).

4 Usp. „Službeni glasnik BiH - Međunarodni ugovori”, br. 8/2010. (29. srpnja 2010.). 
djelovanje karitativnih ustanova, dušobrižništvo zdravstva, zatvora, policije i vojnika, nejasna porezna politika glede neprofitnoga djelovanja crkvenih pravnih osoba, način dobivanja dozvola za gradnju vjerskih objekata itd. Druga prava su pak nerijetko onemogućena, kao što su: neka prava studenata i nastavnika u ustanovama u vlasništvu vjerskih zajednica, puna primjena državnog zakona o slobodi vjere te ugovora koji su potpisani sa Svetom Stolicom i s drugim zajednicama, zdravstveno osiguranje vjerskih službenika, vraćanje dobara oduzetih za vrijeme komunističkoga režima itd.

\section{DepopulaciJa i Denatalitet pogaĐAJu CiJElu BiH}

Nakon posljednjeg rata sveukupno je stanovništvo $\mathrm{BiH}$, prema službenim podacima koji obuhvaćaju razdoblje od 1996. do 2018. godine, zahvatio proces depopulacije, povećanja prosjeka starosti stanovništva, proces vrlo ubrzanoga smanjenja broja rođenih, povećanja broja umrlih i novo iseljavanje. To se odnosi na pripadnike svih etničkih i vjerskih skupina, ali zbog nedostatka odvojenih podataka za svaku skupinu nije moguće napraviti komparativan prikaz, koji bi nas sigurno zanimao. Pa ipak, evo dvaju primjera.

Prvi: Da proces denataliteta pogađa sve skupine dokazuje podatak da je 2018. godine cijela BiH (Bošnjaci, Srbi, Hrvati, ostali), prema službenim podacima, imala negativan priraštaj za -7.779 , a katolici (Hrvati), prema crkvenim izvorima, iste godine su u tomu sudjelovali sa -2.165. To znači da bi iste godine Bošnjaci, Srbi i ostali, uzeti svi zajedno, bili na -5.614 .

Drugi primjer: Da bi se uočio problem depopulacije kao proces, dovoljno je podsjetiti da je, na razini cjelokupnoga stanovništva, BiH 1996. godine imala pozitivan priraštaj za čak 21.442, dok je 2007. godine prvi put imala negativan priraštaj koji je iznosio - 1.209. U međuvremenu je taj negativan priraštaj 2015. godine dosegnuo -8.164, dok je 2018. godine u BiH bilo 7.750 umrlih više negoli rođenih.

Prema konačnim službenim rezultatima popisa stanovništva iz 2013. godine, koje je objavila Agencija za statistiku BiH tek 2016., u $\mathrm{BiH}$ je tada bilo 3.531.159 stanovnika; ${ }^{5}$ ista Agencija nudi također

5 Broj stanovnika BiH za godine od 1996. do 2012. je procjena Agencije za statistiku. Broj stanovnika od 2013. do 2015. rezultat je popisa stanovništva iz 2013. godine prema preliminarnim rezultatima iste Agencije, a broj od 2016. konačni su službeni podaci tog popisa. Rođeni, umrli i priraštaj za sve godine egzaktni su podaci iste Agencije. Usp. AgenciJa za statistiku BiH, Popis stanouništva, kućanstava i stanova u Bosni i Hercegovini. Etnička/nacionalna pripadnost, vje- 
podatke o broju stanovnika, natalitetu, mortalitetu i prirodnom priraštaju stanovništva u $\mathrm{BiH}$ u razdoblju od 1996. do 2018. godine. ${ }^{6}$ Ti službeni podaci preuzeti su od spomenute Agencije i prikazani u sljedećoj tablici (br. 1).

\begin{tabular}{|c|c|c|c|c|}
\hline Godina & Stanovnika & Rođeni & Umrli & Priraštaj \\
\hline 1996. & 3645000 & 46594 & 25152 & 21442 \\
\hline 1997. & 3738000 & 48397 & 27875 & 20522 \\
\hline 1998. & 3653000 & 45007 & 28679 & 16328 \\
\hline 1999. & 3725000 & 42464 & 28637 & 13827 \\
\hline 2000. & 3781000 & 39563 & 30482 & 9081 \\
\hline 2001. & 3798000 & 37717 & 30325 & 7392 \\
\hline 2002. & 3828000 & 35587 & 30155 & 5432 \\
\hline 2003. & 3832000 & 35234 & 31757 & 3477 \\
\hline 2004. & 3842000 & 35151 & 32616 & 2535 \\
\hline 2005. & 3843000 & 34627 & 34402 & 225 \\
\hline 2006. & 3843000 & 34033 & 33221 & 812 \\
\hline 2007. & 3843000 & 33835 & 35044 & -1209 \\
\hline 2008. & 3843000 & 34176 & 34026 & 150 \\
\hline 2009. & 3843000 & 34550 & 34904 & -354 \\
\hline 2010. & 3843000 & 33528 & 35118 & -1590 \\
\hline 2011. & 3840000 & 31811 & 35028 & -3217 \\
\hline 2012. & 3836000 & 32547 & 35817 & -3270 \\
\hline 2013. & 3791622 & 30684 & 35662 & -4978 \\
\hline 2014. & 3791622 & 30268 & 35980 & -5712 \\
\hline 2015. & 3791622 & 29770 & 38150 & -8380 \\
\hline 2016. & 3531159 & 30183 & 36571 & -6338 \\
\hline 2017. & 3531159 & 30200 & 37979 & -7779 \\
\hline 2018. & 3531159 & 28555 & 36305 & -7750 \\
\hline
\end{tabular}

1. Agencija za statistiku BiH: Stanovništvo BiH od 1996. do 2018. godine

roispovijest $i$ materinji jezik / Census of Population, Households and Dwellings in Bosnia and Herzegovina. Ethnicity / National affiliation, religion and mother tongue, Sarajevo 2019.

6 Agencija za statistiku BiH, Demografija / Demography 2916., Sarajevo 2017., str. 24; Agencija za statistiku BIH, Bosna i Hercegovina u brojevima, Sarajevo 2019., str. 8; Agencija za statistiku BIH, Saopćenje / First relase, XIII/ 1, Sarajevo 2019. Vidi http://www.bhas.ba/ - preuzeto 11. listopada 2019. 
Kad se tomu dodaju podaci o iseljavanju, o kojima svake godine izvještavaju nadležne ustanove, onda stvar postaje još očitijom. No nije uvijek prisutna svijest da proces iseljavanja treba promatrati u okviru sličnih događanja u okolnim zemljama, što je u izravnoj uzročnoj vezi i sa stanjem u zapadnim zemljama, koje svoje gubitke stanovništva nastoje nadoknaditi planskim useljavanjem.

\section{SMANJIVANJE BROJA KATOLIKA PONOVNO POSTAO PROCES}

Prisutnost katolika i Hrvata u BiH, izražena u apsolutnim brojevima, prema suvremenim popisima stanovništva (prvi 1879.) bila je u porastu sve do 1971. godine, otkad je u opadanju. Međutim, porast broja drugih, istodobno, bio je mnogo brži i veći, pa je prisutnost katolika, izražena u relativnim brojevima (postocima), prema službenim rezultatima svih popisa stanovništva, u neprekidnom opadanju još od 1931. godine.

Hrvati su 1971. godine (popis prema narodnoj pripadnosti) doživjeli svoj novovjeki apsolutni maksimum (772.491), a godine 1931 . (popis prema vjerskoj pripadnosti) doživjeli su relativni maksimum od 24,01 \%; godine 1991. (popis prema etničkoj pripadnosti) pali su na $17,4 \%$ (760.852). Tako je ponovno uspostavljen stari povijesni proces smanjivanja hrvatske i katoličke prisutnosti u $\mathrm{BiH}$, što prikazuje sljedeći grafikon (br. 2), koji je sastavljen na osnovi procjena nekih znanstvenika i službenih popisa stanovništva. ${ }^{7}$

$7 \quad$ Procjena za polovicu 15. stoljeća preuzeta je od povjesničara Josipa Buturca i Antuna Ivandije, Povijest Katoličke Crkve među Hrvatima, Zagreb 1973., i Dominika Mandića, Etnička povijest Bosne i Hercegovine, ZIRAL, Toronto-ZürichRoma-Chicago 1982. Svi drugi podaci su iz objavljenih popisa stanovništva. Usp. Statistika mjesta i pučanstva Bosne i Hercegovine, Sarajevo 1880.; Statistika mjesta i žiteljstva Bosne i Hercegovine po popisu naroda od 1. maja 1885, Sarajevo 1886.; Glavni rezultati popisa žiteljstva u Bosni i Hercegovini od 22. aprila 1895, Sarajevo 1896.; Die Ergebnisse der Volkszählung in Bosnien und der Herzegowina vom 10. Oktober 1910, Sarajevo 1912.; Stanovništvo Jugoslavije, republika i pokrajina, prema popisu 1921, Beograd 1986.; Definitivni rezultati popisa stanovništva Jugoslavije 1931, po veroispovesti, II., Beograd 1931. Za razdoblje nakon Drugoga svjetskog rata podaci su uzeti iz izvještaja Saveznog zavoda za statistiku, Nacionalni sastav stanouništua SFR Jugoslavije. Podaci po naseljima i opštinama = National Structure of Population in SFR Yugoslavia. Data on localities and communes, I., Beograd 1991.; za godinu 1991. od Republičkoga zavoda za statistiku, Popis stanovništva, domaćinstava, stanova i poljoprivrednih gazdinstava 1991. Prvi rezultati za Republiku i po opštinama, (Statistički bilten 219), Sarajevo 1991. te za 2013 godinu od AgEnCIJE ZA STATISTIKU BIH, Popis stanovništva, kućanstava i stanova u Bosni $i$ Hercegovini. Etnička/nacionalna pripadnost, vjeroispovijest $i$ materinji jezik, Sarajevo 2019. 


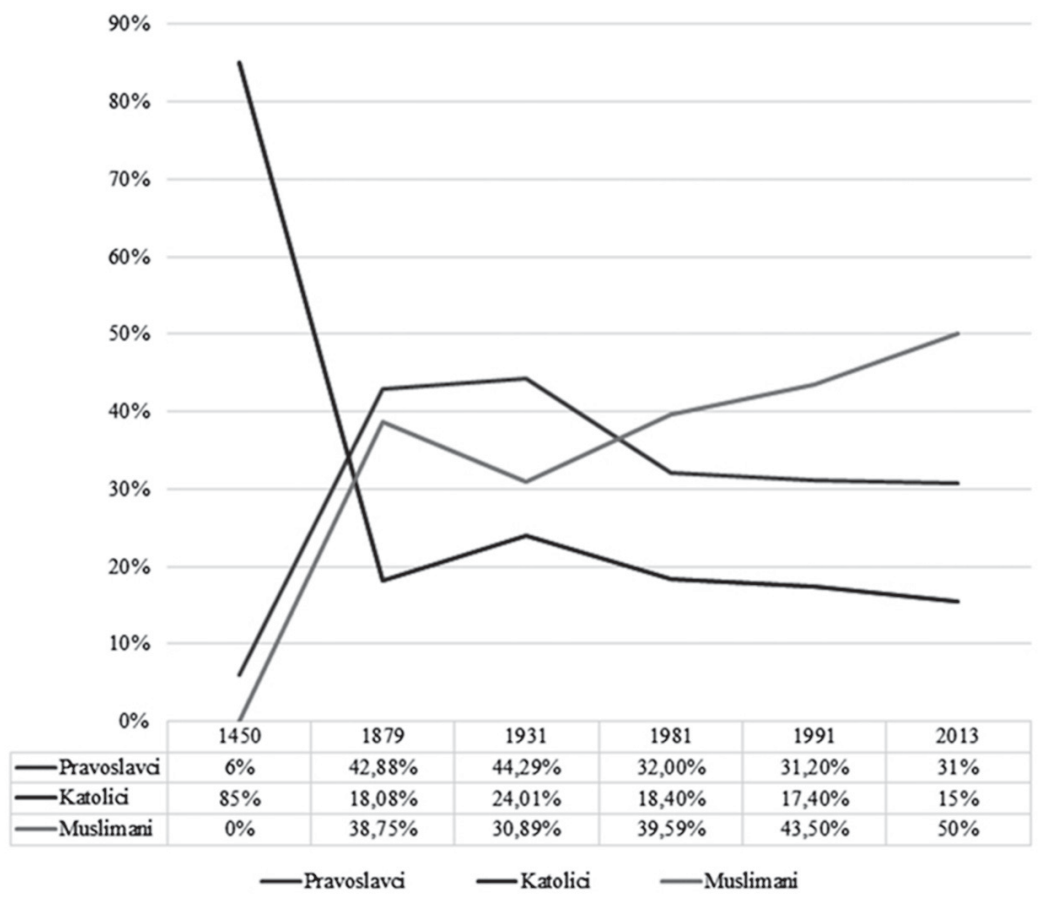

2. Procesi prisutnosti katolika, pravoslavaca i muslimana $u$ $\mathrm{BiH}$

Porast broja Hrvata i katolika u BiH u razdoblju do 1931. godine posljedica je ponajviše doseljavanja za vrijeme austrougarske uprave, a na njihovo smanjivanje nakon toga utjecalo je posebice stradanje za vrijeme Drugoga svjetskoga rata i neposredno nakon njega te pojačano iseljavanje osobito iz ekonomskih razloga koje je uslijedilo nakon 1960. godine.

Tijekom posljednjega rata u $\mathrm{BiH}$ (1991. - 1995.) stradalo je, prognano i raseljeno vrlo mnogo ljudi, kao što se vidi iz sljedeće tablice (br. 3). Zbog toga se etnička i konfesionalna karta u tim krajevima veoma promijenila u odnosu na demografsko stanje i statističke odnose koji su postojali prije toga. Prema rezultatima istraživanja Caritasa $\mathrm{BK} \mathrm{BiH}^{8} \mathrm{~s}$ područja pod vlašću Hrvata protjerano je 112.000 ljudi, što je od ukupnog broja prognanika 9,12\%. Istodob-

8 Usp. Arhiv BK BiH, br. 158-3/99. Podaci o prognanim i raseljenim osobama tijekom rata u $\mathrm{BiH}$ preuzeti su iz izvještaja dr. Miljenka Aničića, nekadašnjeg rav- 
no je s područja pod srpskom vlašću protjerano 586.400 ljudi, što je čak 47,7 \% od sveukupnoga broja prognanika, dok je iz krajeva pod vlašću Bošnjaka protjerano 529.000 ljudi, što je 43,10 \% od broja svih prognanika. Ako se progon definira kao zločin, onda je hrvatsko sudjelovanje u proizvodnji sveukupnoga zločina progona 9,12 \%, bošnjačkoga 43,10\% a srpskoga 47,7\%.

Cjelovit statistički prikaz tragedije ima se tek onda kad se navedenim brojkama prognanih dodaju one koje prikazuju stanje, zbog ratnih strahota, raseljenih osoba $\mathrm{s}$ istih područja, čija stradanja nisu uključena u navedene prikaze. Naime, zbog različitih razloga, koje se ne može svrstati pod pojam izravnoga progona, svoje domove moralo je napustiti, osim onih prognanih, još 154.000 Hrvata, 356.000 Bošnjaka i 217.000 Srba, s time da treba spomenuti i kategoriju „ostalih”, kojih je u BiH 1991. bilo 347.121.

\begin{tabular}{|l|c|c|c|c|}
\hline & Prognano & Raseljeno & Ukupno & Prema 1991. \\
\hline Hrvati & 312.000 & 154.000 & 466.000 & $61,24 \%$ \\
\hline Srbi & 430.000 & 217.000 & 647.000 & $44,24 \%$ \\
\hline Bošnjaci & 485.400 & 356.600 & 842.000 & $47,36 \%$ \\
\hline Ostali & - & - & 156.000 & $44,94 \%$ \\
\hline
\end{tabular}

3. Caritas BiH: Prognani i raseljeni tijekom rata u BiH od 1991. do 1995. godine

Iz ovih je tablica vrlo lako uočiti da su stradanja Hrvata tijekom posljednjeg rata mnogo veća negoli stradanja drugih naroda, jer ta stradanja, kad se zbroje prognanici i raseljeni, iznose čak 61,2\%. Istodobno Hrvati su proizveli neusporedivo najmanje zla te vrste, $9,12 \%$, a često su kriminalizirani više nego drugi.

\section{NEGATIVAN PRIRAŠTAJ I NOVO ISELJAVANJE KATOLIKA}

Službeni rezultati popisa stanovništva iz 2013. godine kažu da je u BiH 544.780 (15,43 \%) Hrvata, 1.086.733 Srba (30,78 \%) te 1.769.592 Bošnjaka (50,1 \%). Prema istom popisu u $\mathrm{BiH}$ je 1.790.454 muslimana, 536.333 katolika, 1.085.760 pravoslavaca,

natelja Caritasa $\mathrm{BK} \mathrm{BiH}$, koji je on predstavio na zasjedanju BK BiH u Banjoj Luci 13. srpnja 1999. 
10.816 agnostika, 27.853 ateista; nije se izjasnilo 32.700 , ostalih je 40.655, onih nepoznate vjerske pripadnosti 6.588.

Broj katolika koji je rezultat istog popisa stanovništva (536.333), dosta je veći od broja katolika kojim raspolažu nadležne ustanove Katoličke Crkve. Naime, prema izvještajima biskupskih ordinarijata, koji su prikupljeni od svih župnih ureda na području pojedinih biskupija, procjenjuje se da je u $\mathrm{BiH}$ na kraju 2018. godine bilo 365.688 katolika, što bi bilo za 10.446 manje negoli prethodne 2017. godine. ${ }^{9}$

Stoga ostaje otvoreno pitanje: Tko je bliže istini: procjene župnikâ o ukupnom broju katolika i Hrvata, u kojima se može prevariti, ili rezultati službenoga popisa, za koje neki kažu da su manipulirani i „napumpani” i da se najviše zbog toga čekalo čak tri godine na njihovo objavljivanje? No budući da Hrvati u velikoj većini žive u manjim gradovima i seoskim sredinama, gdje župnici dobro poznaju vjernike, njihovi izvještaji vjerojatno su bliži istini o stvarno prisutnim katolicima.

Prema zbirnim podacima Biskupskih ordinarijata iz Sarajeva, Banje Luke i Mostara te Biskupske konferencije BiH, koji su prikazani u sljedećoj tablici (br. 4), prirodni priraštaj katolika u $\mathrm{BiH}$ 1996. godine bio je pozitivan za 1467. On se poslije toga svake godine smanjivao, ali je bio pozitivan sve do 2001. godine. Međutim, od 2002. godine do danas katolici u kontinuitetu imaju negativan priraštaj. Dapače, on stalno opada, tako da je 2018. godine bio čak -2165. Taj je rezultat zbroj odnosa broja krštenja i sprovoda u pojedinim biskupijama: Banja Luka -323, Sarajevo - 1868, Trebinje -42 i Mostar +68. A samo usporedbe radi, 1996. godine Banja Luka je $s$ prirodnim priraštajem bila na samo -4 , Sarajevo na pozitivnih +247 , Trebinje na +96 , a Mostar na čak $+1128 .{ }^{10}$

9 „Demografska prisutnost katolika u Bosni i Hercegovini od 1996. do 2017. Stanje, budućnost, pitanja i pastoralni izazovi”, u: Drago ŠımUnDŽA - Nedilj ko Ante Ančıć, Oče naš. Jedan je Otac vaš. Zbornik radova u čast splitsko-makarskog nadbiskupa dr. Marina Barišića prigodom srebrnog jubileja biskupskog posvećenja, Crva u svijetu, Split 2018., str. 423-451. „Predavanje biskupa Vukšića na V. Međudekanskom susretu u BiH. ,Demografska prisutnost katolika u Bosni i Hercegovini od 1996. do 2017.: Stanje, procesi, budućnost, pitanja i pastoralni izazovi”, http://www.ktabkbih.net/ (26. travnja 2018.), preuzeto 11. listopada 2019.

10 Spomenuti brojevi u ovom odlomku, kao i svi koji slijede u sljedećoj tablici za razdoblje od 1996. do 2018. godine, su zbroj svih krštenja upisanih u matice krštenih i svih upisanih u matice umrlih u svim župama u BiH. Razlika između broja krštenih i broja ukopanih za svaku godinu u tablici upisana je u rubrici „priraštaj”. I dok se brojevi krštenih i ukopanih mogu smatrati točnima, za ukupan broj vjernika to se ne može kazati, jer je podatak o ukupnom broju vjer- 


\begin{tabular}{|c|c|c|c|c|}
\hline & Kršteni & Umrli & Priraštaj & Vjernika \\
\hline 1996. & 6739 & 5272 & 1467 & 424.915 \\
\hline 1997. & 7127 & 5841 & 1286 & 451.385 \\
\hline 1998. & 6779 & 5956 & 823 & 451.208 \\
\hline 1999. & 6736 & 5892 & 844 & 448.186 \\
\hline 2000. & 6409 & 5831 & 578 & 456.058 \\
\hline 2001. & 5734 & 5655 & 79 & 458.110 \\
\hline 2002. & 5543 & 5565 & -22 & 463.687 \\
\hline 2003. & 5256 & 5996 & -740 & 464.821 \\
\hline 2004. & 5184 & 5937 & -753 & 464.694 \\
\hline 2005. & 5244 & 5896 & -652 & 462.690 \\
\hline 2006. & 5146 & 5892 & -746 & 463.131 \\
\hline 2007. & 4915 & 6155 & -1240 & 459.102 \\
\hline 2008. & 4799 & 6214 & -1415 & 454.921 \\
\hline 2009. & 4686 & 6075 & -1389 & 448.147 \\
\hline 2010. & 4726 & 6136 & -1410 & 443.013 \\
\hline 2011. & 4475 & 6252 & -1777 & 443.084 \\
\hline 2012. & 4992 & 6420 & -1428 & 435.562 \\
\hline 2013. & 4327 & 6187 & -1860 & 432.177 \\
\hline 2014. & 4158 & 4819 & -661 & 420.294 \\
\hline 2015. & 4061 & 6510 & -2449 & 405.735 \\
\hline 2016. & 4057 & 6291 & -2234 & 390.241 \\
\hline 2017. & 3977 & 6272 & -2295 & 376.134 \\
\hline 2018. & 4086 & 6251 & -2165 & 365.688 \\
\hline
\end{tabular}

4. Biskupski ordinarijati Sarajevo, Mostar i Banja Luka: Katolici $u$ BiH od 1996. do 2018. godine

nika dijelom stvar procjene župnika i nije uvijek pouzdana informacija. Naime, u manjim i seoskim župama župnici redovito poznaju sve svoje vjernike, no to ne vrijedi posebice za gradske župe, gdje je župnicima gotovo nemoguće znati točan broj vjernika. 
Novo iseljavanje drugi je veliki problem katolika. Prema crkvenim podacima katolici su, nakon preživljene ratne tragedije i početnoga laganog povratka poslije rata, najbrojniji bili 2003. godine, kada ih je bilo 464.821. Otada njihov ukupan broj stalno opada, a posljednjih godina taj pad se ubrzava te je narastao na oko 14.000 godišnje. Prema istim crkvenim izvorima, na kraju godine 2018. katolika je 365.688, što je, u razdoblju od dvadeset godina, gubitak od 99.133, odnosno oko 21,32\%. U tom općem gubitku vlastiti negativan priraštaj sudjeluje $\mathrm{s} 23.214$, što znači, da se iz BiH u tom razdoblju, prema crkvenim procjenama, iselilo 75.919 katolika. A budući da se odseljavaju uglavnom mlađe osobe, dok su u fertilnim godinama, to već sada ima velike posljedice na prosječnu dob preostalih vjernika, a za budućnost najavljuje opasne posljedice glede nataliteta.

Nakon posljednjeg rata Banjolučka biskupija imala je najviše vjernika 1999. godine, Sarajevska 2002., Mostarska 2006., a Trebinjska 2005. U odnosu na te njihove pojedinačne poslijeratne maksimume, demografski gubici nastali nakon toga u našim su biskupijama postali novi opasan proces. Tako je novim iseljavanjem i negativnim priraštajem Banjolučka biskupija tijekom posljednjih 20 godina ostala bez 45,71\% vjernika (-24.095) koji su bili na području biskupije 1999. godine, Sarajevska bez 32,48 \% (-70.782) u odnosu na 2002. godinu, Mostarska bez 11,75 \% (-22.845) nakon 2006., a Trebinjska bez 13,04 \% (-2.773) od 2005. godine. U tom događanju posebice velike posljedice ostavit će odlazak intelektualaca raznih profila.

Nakon što je broj Hrvata i katolika u BiH krajem 20. stoljeća gotovo prepolovljen zbog ratnih progona, raseljavanja i iseljavanja, demografski pad katolika i Hrvata u $\mathrm{BiH}$ u razdoblju nakon toga posljedica je istodobnog djelovanja mnogih uzroka. Među njima najvažniji su: izostanak političke i materijalne potpore povratku prognanika i raseljenih; vrlo negativan prirodni priraštaj; novo iseljavanje; visoka stopa nezaposlenosti koja potiče iseljavanje $u$ potrazi za poslom; politička i pravna nesigurnost; korupcija i frustracija; novo iseljavanje kao posljedica planova razvijenih zemalja da nadoknade vlastite demografske gubitke i dobiju radnu snagu; nedovoljna društvena i materijalna potpora ženama koje žele rađati; sve veća kriza bračnog morala i sekularizacija; kriza svijesti kod vjernika o vrijednosti života i roditeljskoj suradnji s Bogom stvoriteljem; odlazak mladih i visoka prosječna dob stanovnika kao razlog neplodnosti itd. 


\section{ULOGA DRŽAVNE VLASTI I MEĐUNARODNE ZAJEDNICE U TRAŽENJU RJEŠENJA}

Traženje pravednoga političkog rješenja za sve u BiH, a time i složenog problema katolika i Hrvata, obveza je državne vlasti i međunarodne zajednice. I budući da je to prvenstveno političko pitanje, te iako ga crkvene osobe nisu pozvane rješavati, ipak je potrebno, barem ukratko, podsjetiti na neka načela socijalnoga nauka Crkve radi uspostave pravednog ustroja. Tako, od sudbinske je važnosti da se državna vlast ozbiljno zauzme za stvaranje ozračja sigurnosti svake vrste. U okviru toga posebice bi bilo korisno podizanje političke i pravne sigurnosti cijeloga društva i ustavnopravne jednakosti svih pojedinaca i naroda, koja ce pogodovati gospodarskom razvitku, bez kojega je gotovo nemoguće zaustaviti iseljavanje te podignuti natalitet. Od presudne bi koristi bilo da se donese državni plan demografske obnove i omogući povratak onima koji to žele. Tomu bi pridonio i pravedan teritorijalni i upravni preustroj cijele države $\mathrm{u}$ pravcu federalne reorganizacije cijele $\mathrm{BiH}$ na način, kako je to nekada davno učinjeno u npr. Švicarskoj ili Belgiji. Na lokalnoj razini, Hrvati stalno trebaju osnaživati i njegovati svoje ustanove nacionalne kulture i znanosti, a od velike koristi bilo bi također definiranje osnovnih interesa naroda, koje bi sve hrvatske snage promovirale i zastupale kroz demokratizaciju političkog djelovanja stranaka i održavanje dobrih veza s Hrvatskom i svjetskim centrima moći.

Državna vlast u Republici Hrvatskoj svake godine daruje nemala sredstva pomoći Hrvatima u BiH. Ipak, volio bih da se mnogo više tih darovanih sredstava ulaže u stvaranje radnih mjesta i gospodarski razvitak hrvatskih krajeva, jer samo to će zadržati naše ljude.

Iako je, u smislu materijalne obnove, vidljiv napredak u posljednjih dvadesetak godina, još uvijek postoji velika potreba liječenja psiholoških rana i dubokih trauma nastalih za vrijeme posljednjeg rata. Stoga se, kao apsolutan prioritet, nameće potreba uspostave legalnih, društvenih, političkih, kulturnih, vjerskih i gospodarskih pretpostavki radi izgradnje i uspostave pravednoga i trajnoga mira, utemeljenog na dijalogu u punom poštivanju prava pojedinih osoba i triju konstitutivnih naroda. A radi postizanja te svrhe, potrebna je konkretna suradnja svih sastavnica društva, uključujući one vjerske. 


\section{JOŠ NEKI IZAZOVI KATOLIČKE CRKVE U SLOŽENOM DRUŠTVU $\mathrm{BIH}$}

Vrlo je važno znati da je hrvatski narod, o kojemu je ovdje govor, uz rijetke i drage iznimke, kao što je na primjer zajednica ukrajinskih grkokatolika, jedina živa Katolička Crkva u BiH. To jest, ako ima Hrvata u BiH, ima i Katoličke Crkve u tim krajevima.

Obveza je ponavljati božansko pravo Crkve da bude po svem svijetu, pa i u $\mathrm{BiH}$. To je također potrebno i radi jačanja njezina kredibiliteta i unutrašnjeg jedinstva, radi uspostave pravednoga društva i radi davanja doprinosa u traženju poštenih rješenja za sve ljude, radi čuvanja zajedništva naroda. U tom bi smislu za Katoličku Crkvu, na lokalnoj razini, bila vrlo važna provedba Temeljnog ugovora sa Svetom Stolicom, koji je potpisan još 2006. godine, kao i onoga u vezi s Vojnim ordinarijatom (2010.) te Zakona o slobodi vjere i pravnom položaju Crkava i vjerskih zajednica (2004.). Međutim, u ovom času nema naznaka da državna vlast to namjerava učiniti. I možda upravo primjer ignoriranja i neprovođenja vlastitog Zakona i tih dvaju međunarodnih ugovora ponajbolje oslikava kakav je stvarni odnos vlasti prema katolicima i njihovoj Crkvi.

Gledano iz katoličke perspektive, međureligijski dijalog je općekatolička misao Drugoga vatikanskog sabora, a na licu mjesta on je egzistencijalna i moralna potreba naše svakodnevice, jer se radi o zemlji koju nastavaju ljudi triju velikih vjerskih zajednica. Nastavaju je i različiti narodi. U njoj su prisutne također razne kulture i civilizacije: srednjoeuropska kršćanska i mediteranska kršćanska te bizantinsko-pravoslavna i bizantinsko-osmanska. Njihovi pripadnici, $\mathrm{k}$ tomu, tradicionalno žive zajedno $\mathrm{u}$ istim gradovima i selima i stoga su predodređeni za međusobnu suradnju. Međutim, zamisao i praksu dijaloga, metodologiju koju se pri tomu slijedi i svrhu dijaloga vjerske zajednice i društvene strane, kako po svijetu tako $\mathrm{u} \mathrm{BiH,} \mathrm{ne} \mathrm{razumiju} \mathrm{jednako} \mathrm{niti} \mathrm{vrše} \mathrm{na} \mathrm{isti} \mathrm{način,} \mathrm{što} \mathrm{je} \mathrm{otvoreno}$ pitanje i velik problem.

Katoličke, pravoslavne i muslimanske odgojne ustanove organiziraju, ponajviše na inzistiranje katoličke strane, konkretne oblike suradnje, kao što su studijski susreti, karitativna djelatnost, posjeti studenata i mladih, no poželjna bi bila aktivna teološka i svaka druga suradnja, koja bi bila izvorno vjerska.

U nastojanju oko općega dobra u BiH, budućnosti Katoličke Crkve i hrvatskoga naroda na tom području svaki oblik solidarnosti pomaže katolicima koji su još uvijek ondje. Na njih treba biti 
stavljen naglasak sveukupne brige, konkretne pomoći i planiranja budućnosti, jer oni su dokaz da Crkve ima u BiH i jamstvo da će je biti. Njima na vrlo konkretan način pomažu brojni dobri ljudi i dobrotvorne ustanove, a ponajviše crkvene, kada imaju sredstava i koliko mogu. I kamo sreće da se to može kazati također za međunarodnu zajednicu koja je, prema nekim izvorima, ${ }^{11}$ katolicima dodijelila samo oko tri posto od ukupne pomoći koju je unijela u BiH.

Najviše smo zahvalni vladi Republike Hrvatske, Hrvatskoj biskupskoj konferenciji, biskupijama, svećenicima, redovništvu i pojedinim vjernicima za iskreno zanimanje, brojne molitve i darove. Među tim pokazateljima solidarnosti je i ovaj Međunarodni teološki simpozij s temom „Crkva između iseljavanja i useljavanja” Katoličkoga bogoslovnog fakulteta u Splitu, na kojemu ste predvidjeli također temu o iseljavanju, a samim time o demografskom stanju i procesima koji pogađaju hrvatski narod i Katoličku Crkvu u BiH. Osobito vidljiv znak toga je Tjedan duhovne i materijalne veze i solidarnosti s Crkvom u BiH, koji se u svim biskupijama u Republici Hrvatskoj organizira svake godine, a prikupljena sredstva daruju se potrebitima. Važno je to jer ni jedna naša biskupija nema siguran izvor prihoda te zato ne može imati ni proračun. Isto vrijedi i za Biskupsku konferenciju BiH. U materijalnom smislu živimo zahvaljujući Providnosti, koja budi darežljivost naših vjernika i dobrih ljudi i ustanova u inozemstvu. Zahvalni smo za veliku solidarnost svojih vjernika i vas dobrih ljudi i ustanova.

\section{ZAKLJUČAK}

Na smanjenje broja katolika i Hrvata u BiH tijekom posljednjih desetljeća utjecalo je i utječe nekoliko ključnih razloga: ratni progoni i raseljavanje; neuspio povratak i sprječavanje održivoga povratka prognanika i raseljenih nakon rata; novo iseljavanje zbog ekonomskih razloga, neriješenoga nacionalnog pitanja, raširene korupcije, političkoga ponižavanja i nezadovoljstva zbog mnogih drugih nepravda u društvu; problem negativnoga priraštaja.

Povratak ratnih prognanika i raseljenih i ispravljanje nepravda koje su tim ljudima nanesene ostaju velika pravna i moralna obveza. No mnogi od tih ljudi na drugim su stranama tijekom proteklog

11 „Biskup Komarica: Nada ne smije nikada umrijeti”, 24. prosinca 2016. https:// www.slobodnaevropa.org/; „Biskup Komarica: Nije istina da se Hrvati ne žele vratiti”, 16. svibnja 2012. http://www.ktabkbih.net/; „Bh. Hrvatima dodijeljeno tek tri posto međunarodne pomoći”, Večernji list 18. svibnja 2012. (https://www.vecernji.ba/. 
vremena našli rješenje za svoje egzistencijalne probleme. Zbog toga pitanje povratka sve više postaje prošlost. Zato, radi budućnosti Crkve i naroda u $\mathrm{BiH}$, prioritet treba biti ostanak katolika i Hrvata koji još uvijek ondje žive, te stvaranje gospodarskih, političkih, pravnih i svih drugih uvjeta za njihov ostanak u BiH.

\section{THE DWINDLING NUMBER OF CATHOLICS IN BOSNIA AND HERZEGOVINA AND THE NEED TO STOP IT}

\section{Summary}

After the number of Croats and Catholics in B\&H was almost halved at the end of 20th century due to war persecution and displacement, emigration and negative growth became their new major problem. According to church data, after surviving the war tragedy and an initial slight comeback after the war, with new emigration and negative growth, the Catholic Church in B\&H from 2003 to 2018 registered a loss of 99,133 believers. In other words, during the last 20 years, the Diocese of Banja Luka has lost $45.71 \%$ of believers, who were in the diocese in 1999. The Diocese of Sarajevo has lost $32.48 \%$ compared to 2002. The Diocese of Mostar has experienced a loss of $11.75 \%$ after 2006. And finally the Diocese of Trebinje has lost $13.04 \%$ since 2005. In this general loss according to church estimates, 75,919 Catholics emigrated from B\&H during that period resulting in negative growth of 23,214 people.

The demographic decline of Catholics and Croats in B\&H after the war is the consequence of many simultaneous causes. The most important among these are: lack of political and material support for the return of refugees and displaced persons; very negative natural growth; new emigration; high unemployment rates that encourage emigration in search of employment; political and legal uncertainty; corruption and frustration; new emigration as a consequence of plans by developed countries to replace their own demographic losses and to gain labour workers; insufficient social and material support for women who wish to give birth; the growing crisis of marital morality and secularization; a crisis of awareness among believers about the value of life and parental collaboration with the Creator God; young people leaving, and the high average age of the population, etc. 
Croats in $\mathrm{B} \& \mathrm{H}$ are frustrated by the unjust internal division of the state into two entities, whose administrative structure in both cases is to their detriment, the unresolved national issue, and the fact that the electoral will of individuals and peoples is undermined by electoral law. In other words, since others often decide who their representative will be, many Croats feel disenfranchised and humiliated.

Bosnia and Herzegovina, a complex country of three constituent peoples and other citizens, finds itself in the middle of maintaining its current state, federalization, unitarism and secessionism. It also contains various cultures and civilizations: Central European, Christian, Mediterranean, Byzantine Orthodox and Byzantine Ottoman. This is why sincere dialogue is an existential need; a means of building a just peace, social harmony, the healing of wounds from a difficult past, and empowering the religious community's own awareness and call to be the moral vertical of society.

The quest for a just political solution for all in $\mathrm{B} \& \mathrm{H}$, and thus the solution of the complex problems of Catholics and Croats, is the responsibility of the state government and the international community. But it is necessary to keep in mind the Church's social doctrine: it is of crucial importance that the authority makes every effort to create an atmosphere of security. In this context, it would be particularly useful to increase the political and legal certainty of the whole society, as well as the constitutionally legal equality of all, which will favour economic development. A just territorial and administrative reorganization of the entire state into a federal system for the whole of $\mathrm{B} \& \mathrm{H}$ would contribute to this. At the local level, Croats need to constantly strengthen and nurture their institutions of national culture and science, and it would also be of great benefit to define the basic interests of the peoples, which all Croatian forces would promote and represent through the democratization of political activities of the parties and the maintenance of good relations with Croatia and the world centers of power.

At the same time, Croatian people, referred to here, with some exceptions, are the only living Catholics and members of the Catholic Church in B\&H. Thus, if there are Croats, there will be also the Catholic Church. This awareness is a prerequisite for any other form of real solidarity. In addition, it is the divine right of the Church to be present throughout the world for the salvation of men. Therefore, its credibility and internal unity should be strengthened, in order to establish a just society and to contribute to the search for fair solutions for all people. In this regard, implementation of the Basic 
Treaty with the Holy See (2006), as well as the Treaty with the Military Ordinariate (2010) and the Law on Freedom of Religion and the Legal Status of Churches and Religious Communities (2004) would be very important for the Catholic Church in B\&H.

Keywords: decrease in the number of Catholics and Croats, persecution, emigration, negative growth, failed return, lack of work, search for a solution, state power, international community, Church response 